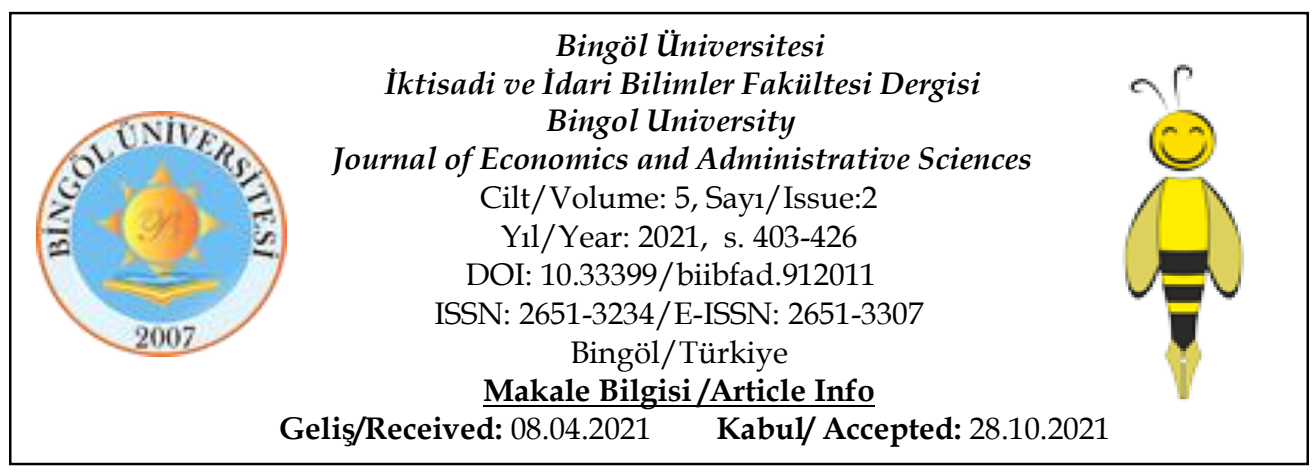

\title{
PERCEIVED UTILITY: AN EXPERIMENTAL STUDY IN BEHAVIORAL ECONOMICS*
}

\section{Algılanan Fayda: Davranışsal İktisat Ekseninde Bir Deneysel Çalışma}

\section{İbrahim CEVİLLi் $\dot{I}^{* *}$ Mahmut BİLEN**}

\begin{abstract}
In the 18th century, when rationality was accepted and the belief that people are selfish due to their natural nature, the first effort of economics, which aimed at human as a social science, was to provide the individual with a universal structure based on the basic assumptions of "rationality and selfishness". The goal of this individual was also defined as "maximizing utility". Ultimately, "Homo-economicus", that is, "Rational Economic Individual", took place. In this study, the phenomenon of utility maximization, which the science of economics is based on when defining the individual, has been analyzed with an experimental study from the perspective of behavioral economics. The research demonstrates its importance by aiming to show the impact of perceptions on utility that are ignored by mainstream economics (Neoclassical economics). The research includes soldiers in a military unit in Yalova/TURKEY. In the study, analysis was carried out by tasting the same product

\footnotetext{
* Bu çalışma, Mahmut Bilen danışmanlığında İbrahim Cevizli tarafından Sakarya Üniversitesi Sosyal Bilimler Enstitüsü İktisat Anabilim Dalında hazırlanmış "İktisatta Rasyonel Birey Analizi: Davranışsal İktisat Ekseninde Bir Deneysel Çalışma" isimli doktora tezinden üretilmiştir. The ethics committee approval" from the Ethics committee.

*** Dr., ibrahimcevizli@hotmail.com, ORCID: https://orcid.org/0000-0002-1516-5081

*** Prof.Dr., Sakarya Üniversitesi Siyasal Bilgiler Fakültesi, bilen@sakarya.edu.tr, ORCID: https://orcid.org/0000-0002-8512-5528
} Committee of University of Sakarya (No: 40/02, Date: 01.12.2021) was obtained. The study was conducted within the set framework of the principles of the ethics
\end{abstract}


with different price tags to two different groups of subjects. It was concluded from the experiment that $60.7 \%$ of the subjects moved away from the rationality assumption by getting the perception of "price and surprise". In this context, this study is an original study by revealing the "perceived benefit" phenomenon.

Keywords: Behavioral economics, experimental economics, rationality, individual, utility, perceived utility

Jel Codes: B21; C9; D01

\section{Öz}

Rasyonelliğin (akılcığın) kabul edildiği ve insanların doğal yapısı gereği bencil olduklarına olan inancın hâkim olduğu 18' inci yüzyılda sosyal bir bilim olarak insanı gaye edinen iktisadın, ilk gayreti bireyini "rasyonellik ve bencillik" temel varsayımları üzerinden evrensel bir yapıya kavuşturmak olmuştur. Bu bireyin amacı da "faydasını maksimize eden" olarak tanımlamıştır. Nihayetinde de 'Homo-economicus" yani "Rasyonel İktisadi Birey" vuku bulmuştur. Ancak bilişsel kısıtlara vurgu yaparak ortaya çıkan davranışsal iktisat, ana akım iktisadın birey tanımlamasında göz ardı edilen hususlara dikkat çekerek mevcut teorilerin geçerliliklerinin daha da artırılabileceğini öne sürmektedir. Bu çalışmada temel olarak iktisat biliminin bireyini tanımlarken esas aldığı fayda maksimizasyonu olgusu davranışsal iktisat perspektifinden bir deneysel çalışma ile analiz edilmiştir. Araştırma, ana akım iktisat (Neoklasik iktisat) tarafından göz ardı edilen algıların fayda üzerindeki etkisini göstermeyi amaçlayarak önemini ortaya koymaktadır. Araştırma Yalova/TÜRKIYYE'de bulunan bir askeri birlikteki askerleri kapsamaktadır. Çalışmada iki ayrı denek grubuna aynı ürün farklı fiyat etiketleri ile tattırılarak analiz gerçekleştirilmiştir. Deneyden deneklerin \%60,7'sinin “fiyat ve şaşırtmaca" algısına kapılarak rasyonellik varsayımından uzaklaştığı sonucu elde edilmiştir. Bu kapsamda bu çalışma "algılanan fayda" olgusunu ortaya çıkartarak özgün bir çalışma niteliğini taşımaktadir.

Anahtar Kelimeler: Davranışsal iktisat, deneysel iktisat, rasyonalite, birey, fayda, algilanan fayda.

Jel Kodlar: B21; C9; D01

\section{Introduction}

The idea that there is no legitimate authority to consult outside the mind, which started in the West in the 18th century and later turned 
into a social project with enlightenment, spread to the epistemology of the period, thus forming the main factor in the natural sciences (especially physics) to become modern science. Thus, thoughts with a dogmatic nature are excluded from the scope of scientific knowledge. In this period, when the winds of positivism were blowing, economics sought a balance as in physics by imitating the science of physics in an effort to become an original science. If economics is going to be a science like physics, it is inevitable that the language it will use will also be mathematics (Y1lmaz, 2009: 25-62).

Economics is a social science. The main purpose of social sciences is human. In this period when mind came to the fore and physical sciences were accepted as modern science, the first effort of economics was to bring homoeconomicus to a universal structure based on the basic assumptions of rationality and selfishness. Acting in line with these two assumptions, the economic individual accepted the aim as maximizing its utility. The phenomenon of utility maximization with preferences theory explained later; It has become concrete as minimizing the cost under a certain budget constraint and increasing the amount of goods consumed.

Having completely got rid of its psychological and philosophical roots and internalized mathematics, economics has developed theories and policies in this direction. Mathematicalization transformed from being a tool to a goal, attracting mathematical operations and focusing on predictive power rather than reality. As a result; Economics turned into a technical science by being instrumentalized and abstracted, and it forgot the real person. In such a powerful paradigm, it is difficult to analyze the assumptions of economics from a different perspective (Yilmaz, 2009: 64-99).

In a situation where needs are unlimited and resources are limited, mainstream economics is based on the fact that the equilibrium condition can be met with the condition of optimization. According to this condition, individuals behave in a way that maximizes their utility under the assumption of rationality. However, perceptions have begun to take the place of reality in many areas of our lives. This situation not only increases the importance of psychological and cognitive 
processes, but also causes some of the presuppositions of mainstream economics to be questioned. People cannot always behave in a way that maximizes their utility due to cognitive, intuitive and emotional influences (Dumludağ et al., 2018: 107-130). People's perceptions have an impact on many decision processes, including utility.

Neoclassical economists, who put benefit at the center of their analysis and developed mathematical methods to measure it, predicted that their theories would be more valid, required certain presuppositions in order to universalize human behavior from the 19th century and put forward the homoeconomicus assumption. As a result, the economic individual has reached a structure that is easier to understand through mathematical methods (Mullainathan and Thaler, 2000: 1094). However, the multidisciplinary study of economics and psychology sciences, which has caused this assumption to become controversial today, has led to the emergence of the field of behavioral economics. Experimental economics emerged as a result of behavioral economics employing experimental methods because it includes real people. The study of experimental economics in the brain structures of individuals in economic decision processes by using advanced technology has led to the birth of neuroeconomics.

When the concept of utility, which requires an objectivist approach, is subjected to a wide analysis, it appears as a phenomenon affected by psychological and neurological situations. It is accepted that neoclassical economics follows a rational behavior in determining the needs of people according to the principle of rationality (Küçükkalay, 2008: 230). In addition, many economists working in the field of behavioral and experimental economics include concepts such as emotion, altruism, trust, and happiness that are ignored by mainstream economics. Especially it seems that Kahneman has opened up this objectivist attitude of mainstream economics to discussion. Claims that people do not always know what they want, that they are limited rational and cannot maximize their utility always provide a solid foundation (Gökdemir ve Öztürk, 2018: 200).

Preferences, attitudes, and behaviors ultimately form in the human brain. It is not easy to examine such phenomena within the scope of 
social science. The assumption of utilitarianism and rationality emerges as the basic assumptions attributed to the individual by neoclassical economics (Eren, 2011: 17). When these assumptions and theories are examined, it is seen that psychological, sociological and biological factors are excluded from the definition of the individual, and the individual is tried to be defined by mathematical operations.

This study includes 56 soldiers in a military unit in Yalova/TURKEY. In this study, the benefit perceptions of individuals were analyzed with an experimental application to be carried out on the sense of taste. At the same time, the benefit maximization condition and the theory of explained choices were analyzed. The research demonstrates its importance by aiming to show the impact of perceptions on utility that are ignored by mainstream economics (Neoclassical economics). As a result of the study, it was revealed that the individuals behaved as a result of the perceived benefit. In this context, this study is an original study by revealing the perceived benefit phenomenon.

\section{Utility in Economics}

The philosophical origin of the concept of utility is based on the word "pragma" from the ancient Greek language (Mendelson, 2002). Although the first pioneer of hedonistic thought was Aristippos and Epicurus, which was influenced by him and worked on the continuity of pleasure, Bentham stands out as the founder of the school of utilitarianism. Bentham defined utility as the pleasure, happiness left by the use of an object, and said that this is also a universal validity (Bentham, 1996: 21).

After Bentham, studies for the utility in the history of economics are divided into two according to whether the utility can be measured (cardinal/numerical) and cannot be measured (ordinal/ordered). Gossen first declared in 1854 that utility is measurable and included cardinal utility in his work. Thus, cardinal utilitarians, who argue that they can measure utility with a unit of measurement called Util, took place in the literature. As it is known, Alfred Marshall, who followed this trend, developed the demand theory from the diminishing marginal utility theory (Dinler, 2015: 31-37). 
According to the cardinal utility theory, the utility of any good or service that can be consumed can be measured and expressed in a certain number. The utility to be obtained from the combination of goods or services depends on the amount to be consumed for each of the goods and services constituting it (Bulmuş, 2008: 22). In theory, as the amount of goods consumed increases, the total utility obtained by individuals increases. For example, when 1 unit of goods is consumed, the benefit obtained is 100 util, while the benefit increases as a result of 2 units of consumption and reaches 200 util.

Edgeworth, Pareto and Hicks succeeded in getting rid of the cardinal utility current and worked on the ordinal utility concept. Hicks and Allen substituted the word utility with the word preference (Hicks and Allen, 1934: 54). According to those who defend this trend, the utility cannot be measured. However, the individual can sort the goods according to the benefit they provide. Edgeworth and Pareto used indifference curves in their analysis to rank these preferences. With this analysis, it has also been revealed that the benefit is not a function of the quantity of goods consumed, but also a function of other goods. The elasticity of demand was improved by Slutsky, Hick and Allen, so the newly formed indifference curves gave the demand theory a more robust structure than Marshall's. In addition, with the Explained Choice Theory, Samuelson analyzed consumer behavior in an ordinalist framework and showed that the consumer made choices in a way that maximizes the benefit under budget constraint (Frey and Stutzer, 2002: 404). After the Ordinalist revolution, the definition of utility changed and started to be shown with the economic basis. In particular, as a result of the breakdown of economics from the science of psychology, the concept of utility has been defined only with objective concepts, without subjective facts. In ordinalist theory, consumers always act in search of the least or the most. This situation shows that they are constantly pursuing a goal. However, they have a limited budget to meet the needs of consumers. They prefer the combination of goods and services that will benefit them the most with their limited budgets.

Mainstream economics has basically adopted the positivist method and has chosen to calculate individual benefit with concrete tools. 
Assuming that the individual behaves rationally, economics focuses on the choices that will provide the most benefit, and excludes subjective values. Especially in micro-economic models, only objective elements have been included, and subjective values have been eliminated by using Occam's Razor ${ }^{1}$. While classical economists analyzed utility maximization and known results, neoclassical economists associated rationality with utility (Frey and Stutzer, 2002: 402-435).

Since the utility approaches addressed in economics are based on subjective values, other factors that have an effect on utility have been ignored. However, there are other factors that affect the benefit, especially perceptions. When evaluated from this perspective, there is a need to increase the validity of the utility phenomenon by supporting it with different studies. As a matter of fact, people can obtain different benefits by developing different perceptions in the face of a neurophysiological process that starts from the language and goes directly to the brain, even if two products are the same. In the next part of the study, the utility perceptions of the subjects were analyzed with an experimental study conducted on the sense of taste. As a result, the concept of perceived utility has been reached.

\section{Taste and Perception}

Information is constantly coming to the human mind through the sense organs. We tend to discover our world by our sense organs. It is known that a normal person produces eleven million pieces of information per second and sends it to the brain. However, the capacity of the brain to consciously process information is at most 50 information per second (Mlodinow, 2013: 51). This information goes through many stages in the registration process. It can be ready to be

\footnotetext{
${ }^{1}$ Occam's Razor was proposed in the 14th century by William of Ockham. Although the original is Ockham, it is mostly used as Occam in the literature. According to this principle, a phenomenon should be explained with the least possible assumption. Ockham is a town in the south east of England.
} 
used after all these processes. Each individual can interpret these data differently due to factors such as emotions, thoughts, and lifestyle. The ability of the mind to acquire and comprehend information through thought, experience and sense is called cognition. Cognitive functions are defined as activities involving understanding, comprehension and recognition. Cognitive functions in general; consciousness, orientation, attention, perception, decision making, problem solving, memory, intelligence, knowledge base, literacy capacity, abstraction / concrete thinking, visual-spatial ability (Kirpınar, 2019: 25-32).

It is called sensation that innumerable stimuli coming from our environment reach the brain in the form of a nerve flow by stimulating the cells. That is, sensation is a neurophysiological process and begins with arousal by a sensory receptor. Stimulants from the outside world first trigger the receptor cells in our sensory organs. This triggered receptor cell converts energy into nerve energy and transmits it to the brain. It is known that we have five basic sensory organs: vision, hearing, taste, smell and touch (Kirpinar, 2019: 77-79). In this study, the sense of taste will be explained here, as an experiment was conducted on the sense of taste.

As is known, the sense of taste is realized by the tongue sense organ. Although it is not possible to see it with the eye, there are pits called papillae on the outer surface of the tongue. There are taste cells / buds in these holes, and about fifty nerves / receptors inside the taste cells. It is known that an adult healthy person has an average of 9000-10000 taste cells in their mouth. The chemical structure of a food touching the tongue is dissolved with saliva and enters the space called Papillae, the current formed as a result of the taste cells firing the nerves is first sent to the periatal lobe in the brain and then to the limbic system in this lobe. This process takes place in about ten tenths of a second (Kirpinar, 2019: 96-97).

The process of making sense of sensory inputs is called perception. Perception is much more than copying a sensation to the brain. Even if the image is stable, perception may vary. Perception can also be considered as a state of organization. Incoming senses are compiled, collected, organized and given meaning. In other words, perception 
expresses much more than the sensory inputs that make up itself. Gestalt Psychology, born in the 1890s as a reaction to the atomistic approach, says that perception means more than the sum of individual parts. This situation can be exemplified by listening to the melody with integrity instead of listening to individual notes while listening to music. It loses its meaning if the whole is disassembled (Kırpinar, 2019: 100-103).

To summarize in general, while sensation is a physiological event, perception is completely a psychological state. While judging, perceiving and understanding events, our brain may react differently from the rational individual assumption. After all, we are creatures that move in parallel with each other and live in mutual interaction, unlike computers that can directly process incoming data. This is why modern psychologists and neuroscientists recommend reviewing the assumption in economics textbooks that people make decisions in ways that maximize their interests. Indeed, behavioral economists such as Antonio Ragel from California Institute of Technology (caltech) continue to question this way of thinking of economics by providing strong evidence on this issue.

\section{Literature Review}

Of the studies on this situation in the literature; In the experiment on detergent, the subjects were given detergent in three different boxes. They were asked to try them and report which one was better at the end of the experiment. One of these three boxes is yellow, the other is blue, and the third is a colored box with yellow spots on it. At the end of the trial, most of the subjects reported that the detergent in the box with blue-on-yellow spots cleans better. In fact, all three boxes contain the same detergent. The subjects were unwittingly affected by the colors in the boxes and concluded that the detergent in the box with yellow spots over blue cleans better (Packard, 1957). This is the reason why people in the profession groups such as contractors and real estate agents making promotions by wearing beautiful clothes is due to this.

In another study, wine research, four French and four German wines, similar in price and quality, were placed on the same shelf in a UK market. The genres of music played in the market are deliberately 
planned to be French music one day and German music the next. According to the data obtained as a result of the observation, it was seen that $77 \%$ of the wines sold on the days when French music played was French wine, and $73 \%$ of the wines sold on the days when German music played was German wine. According to the result of this research, the music played in the market was effective in product selection (North, Hargreaves and McKendrick, 1997).

In the study about socks, four pairs of socks were given to the subjects and they were asked to examine their fabrics in terms of quality. The socks are exactly the same. However, light but different scents were applied to each of the socks. As a result of the experiment, it was observed that the majority of the subjects chose the stocking with which a certain scent was applied (Laird, 1932: 241-246).

In the study called Pepsi Challenge in the literature, the eyes of the subjects were closed and Pepsi was tasted with Coca Cola, respectively. At the end of the trial, the rate of people who liked Pepsi was outpaced compared to the rate of those who liked Cola. However, when they did the same experiment with the same people with their eyes open and seeing what they were drinking, it was observed that those who liked Cola clearly dominated. It is seen that the brand significantly affects the liking process of individuals. During this experiment, the brain image of the subjects was also examined with the f-MRI device. It has been observed that a brand that is adjacent to the orbitofrontal cortex in the brain and known in the ventromedial prefrontal cortex section causes the formation of warm and vague feelings (Paulus and Frank, 2003: 1311-1315).

As a matter of fact, Cevizli and Bilen (2021), who examined the effect of emotions on our rational economic decisions with an experimental study, showed that people can move away from rationality by being affected by their emotions. In their studies, control and experimental groups were formed by dividing the subjects into two separate groups. In the experiment, they were asked how much they would like to transfer from their income of $2350 \mathrm{TL}$ (Turkish Liras) if they were included in the private pension system. The subjects in the control group were requested to do simple mathematical operations 
$(28+11=?, 15 \times 12=?, 105 \div 3=$ ? $)$ Before the experiment to go through the preliminary preparation process. The subjects in the experimental group were asked the same question (the amount they will transfer to the private pension system). However, during the preliminary preparation process, this group was taught a real-life emotional story. According to the rational individual assumption of mainstream economics, the subjects are expected to act without being affected by the emotions they experience during the preliminary preparation process, such as the amount to be transferred to the private pension system. However, as a result of the experiment, it was concluded that the amounts transferred between the two groups differed statistically significantly, and the subjects in the experimental group were affected by the story they read at the time of the decision, so that people could not exhibit pure rational behavior at every moment.

In addition, in the survey study conducted on 388 people in order to determine the direction of consumers' consumption trends and purchasing decisions and whether they differ with their personal characteristics, it was concluded that consumers consume more products and services by being influenced by the symbolic features they have (Yayar ve Oruç, 2020: 35-55). In another study conducted on public employees, it was determined that men act more according to market norms, older individuals provide more self-control, and young people prefer to take more risks compared to older people, and a result opposite to rationality was obtained (Yayar ve Karaca, 2019: 1-29).

Following these analyzes in the literature, in this section, an experimental study to be carried out over the sense of taste and a choice between two products, it is analyzed that individuals develop different perceptions by being affected by things they are not aware of.

\section{Scope and Method of Experimental Study}

This experiment was conducted on 56 soldiers in a military base in 2020 . Thus, the experiment was carried out only on men. The age range of the subjects is 20-30 and their income level before enlistment is between 2500-4000 TL. Subjects have not previously participated in such a study. The education level of the subjects is at least high school graduates; There are also associate degree, undergraduate and 
graduate graduates. The subjects cover all of Turkey's seven geographical. Thus, access to a heterogeneous group of subjects with different cultures was provided.

In the experiment, in order to ensure anonymity, the experiment was carried out in such a way that the subjects were alone. The physical environment and the equipment used are arranged in a way that prevents the subjects from feeling that they are being watched. Information that would highlight their personal characteristics has not been collected from the subjects. Thus, the principle of privacy protection has not been ignored. In addition, care was taken for the subjects to be physically comfortable during the experiment. The experimental instructions were read to the subjects in a clear and plain language and without any effect, including the presentation style, and their understanding was confirmed. In order to encourage the subjects to make their true choices, a cash fee of $10 \mathrm{TL}$ was paid after the experiment. Thus, the condition of monotony required in the incentive mechanism was fulfilled.

The results were not presented in a way to highlight the categorical characteristics of the subjects, since the study did not aim at a statistical / econometric analysis by basically focusing on human. Physically, people's sense of taste decreases as they get older (Kirpinar, 2019: 96). For this reason, in order for the experiment to result in a healthier result, the age range should be It is targeted to be 20-30. The subjects moved away from the factors that could affect the result of the experiment due to their isolation from the outside due to the known period (covid-19). In addition, the presence of people from different cities constitutes an important element in meeting the external validity criteria of the experiment.

Since the experiment will be carried out on the sense of taste, it was started around 16:00. The purpose of starting at this time is that the subjects completed their last eating activities at 13:00 in accordance with their daily life cycle and that they have not eaten anything for about 3 hours. Thus, the possibility of another taste that could affect the result of the experiment before the experiment was eliminated. The experiment was carried out in two stages in a room with two doors. 
There is a table in the room where the experiment is carried out. On the table, there are two identical (color, shape, size, etc.) transparent glass jars and the same breakfast chocolate inside the jars, which do not have anything to create an influence on them. However, the subjects were not informed that they had the same product in both. Unit price labels are placed in front of the jars in order to manipulate the subjects. A. 17.25 TL and B. 21.5 TL are written on the labels. These prices are the prices of Ülker branded breakfast chocolate in a plastic box of 950 gr on May 15, 2020 at BIM and Migros stores. The price of the same chocolate in the BIM market is $17.25 \mathrm{TL}$, while the price of the same chocolate in Migros is 21.5 TL.In the first stage, the subjects tasted these two chocolates, then answered the questions on the paper in front of them, and then folded the paper in half and left it inside the box on the table that was invisible. The box is designed in the form of a ballot box and invisible inside. A small compartment was opened on the box so that only paper could enter, and the other sides were kept completely closed. The first stage of the experiment is completed by throwing all the papers into the box. The questions asked to the subjects in the first stage of the experiment are shown in Table 1.

Table 1: Questions Asked to the Subjects in the First Stage

\begin{tabular}{ccc}
\hline $\begin{array}{c}\text { 1. Which One Do } \\
\text { You Like ? }\end{array}$ & $\begin{array}{c}\text { 2. Write Down Why You } \\
\text { Like In One Word. }\end{array}$ & $\begin{array}{c}\text { 3. If You Were To Buy, } \\
\text { Which One Would You } \\
\text { Buy? }\end{array}$ \\
\hline A. $17.25 \mathrm{TL}$ & A. $17.25 \mathrm{TL}$ \\
$\begin{array}{c}\text { B. } 21.5 \mathrm{TL} \\
\text { C. Indecision }\end{array}$ & B. $21.5 \mathrm{TL}$ \\
\hline
\end{tabular}

The subject who completed the first stage was informed about the same product in both jars by sharing the real situation with him. After the subject learned the fact that both had the same product, the second phase of the experiment started. In the second stage, the subject was given another sheet of paper and asked to answer the questions written on the paper. The subject, who answered these questions, folded the paper in half again and threw it into the box. The questions given to the subject to answer in the second stage are shown in Table 2. 
Table 2: Questions Asked to the Subjects in the Second Stage

\begin{tabular}{cc}
$\begin{array}{c}\text { 1. Why do you think that the price of } \\
\text { 17.25 TL could be chosen / liked / } \\
\text { preferred? }\end{array}$ & $\begin{array}{c}\text { 2. Why do you think that the price } \\
\text { of 21.5 TL could be chosen / liked / } \\
\text { preferred? }\end{array}$ \\
\hline $\begin{array}{c}\text { (write in a single word or a single } \\
\text { sentence) }\end{array}$ & $\begin{array}{c}\text { (write in a single word or a single } \\
\text { sentence) }\end{array}$ \\
\hline
\end{tabular}

After putting the second paper into the box, the experiment ended for the subject and $10 \mathrm{TL}$ was paid to the subject in cash. As can be seen from the tables above, no identifying information that would affect the anonymity was collected in the experiment. There is no communication mechanism between it and other fields as of the location where the experiment was conducted. Therefore, the subjects could not affect each other during the experiment. The day after the experiment, the subjects were asked only the city they lived in.

The Ethics Committee Approval of this study was obtained by the Sakarya University Rectorate Ethics Committee on 01.12.2021, with the decision numbered 40/02.

\section{Experimental Results and Obtained Findings}

The findings obtained from the subjects are shown in the following sections respectively. First, "Which one do you like?" According to the percentage distribution of the answers given to the question asked in the form, $41 \%$ of the subjects liked the breakfast chocolate in jar $\mathrm{A}$, that is, the unit price was 17.25 TL. $52 \%$ of the subjects liked the breakfast chocolate in jar B, which is $21.5 \mathrm{TL}$ per unit. On the other hand, the rate of those who do not make any difference between the two and remain undecided about which one is better appears to be only $7 \%$.

According to the conclusion discussed here, it is concluded that individuals cannot always act with pure mind in daily life and that the assumption of rationality cannot always be valid. Because the individual who acts with his mind should immediately realize that they are the same in the face of this neurophysiological process that starts from the tongue and goes directly to the brain, and should choose the indecisive option by saying that I could not make a difference between the two. Apart from this, the fact that the situation 
is contrary to the assumption of rationality creates a situation. As a matter of fact, when evaluated from this point of view, it is seen that $93 \%$ of the subjects behave contrary to the rationality assumption.

Secondly asked in the experiment, "Please write your reason for liking in one word." The answers given by the subjects to the question as shown in Table 3.

Table 3: Reasons for Liking the Subject

\begin{tabular}{|c|c|c|c|c|c|}
\hline Subject & Choice & Reason for Liking & Subject & hoice & Reason for Liking \\
\hline 1 & A & SOFTNESS FEEL & 29 & A & $\begin{array}{c}\text { B SOME MORE } \\
\text { HEAVY } \\
\text { MORE }\end{array}$ \\
\hline 2 & B & NOT DISTURB & 30 & A & $\begin{array}{l}\text { INTENSIVE } \\
\text { CHOCOLATE }\end{array}$ \\
\hline 3 & A & MORE DELICIOUS & 31 & A & $\begin{array}{l}\text { SWEETER AND } \\
\text { DIFFERENT }\end{array}$ \\
\hline 4 & B & LIGHT AND NORMAL & 32 & $\mathrm{~A}$ & $\begin{array}{c}\text { GIVES MORE } \\
\text { TASTE } \\
\text { THE PRODUCT }\end{array}$ \\
\hline 5 & A & LIGHTER & 33 & A & $\begin{array}{c}\text { LEAVES A } \\
\text { PLEASANT } \\
\text { TASTE }\end{array}$ \\
\hline 6 & $\mathrm{C}$ & INDISTINGUISHABLE & 34 & A & $\begin{array}{l}\text { TEN NUMBER } 2 \\
\text { I LIKE A }\end{array}$ \\
\hline 7 & A & MORE TASTE & 35 & A & $\begin{array}{c}\text { BECAUSE IT } \\
\text { TASTES BETTER }\end{array}$ \\
\hline 8 & A & TASTES NICE & 36 & $\mathrm{~A}$ & $\begin{array}{l}\text { THE PRODUCT } \\
\text { IN B IS SOUR }\end{array}$ \\
\hline 9 & $\mathrm{C}$ & - & 37 & A & $\begin{array}{c}\text { THIS IS } \\
\text { AWESOME }\end{array}$ \\
\hline 10 & B & ORIGINAL TASTE & 38 & A & $\begin{array}{c}\text { MORE } \\
\text { DELICIOUS }\end{array}$ \\
\hline 11 & B & NOT TOO SWEET & 39 & $\mathrm{~A}$ & $\begin{array}{c}\text { TASTES LIKE } \\
\text { HONEY }\end{array}$ \\
\hline 12 & $\mathrm{~B}$ & TASTE BETTER & 40 & $\mathrm{~A}$ & NICE \\
\hline 13 & A & - & 41 & $\mathrm{~A}$ & $\begin{array}{l}\text { TASTES NICE } \\
\text { CHOCOLATE }\end{array}$ \\
\hline 14 & B & STUNNING BEAUTIFUL & 42 & B & $\begin{array}{c}\text { MORE } \\
\text { INTENSIVE }\end{array}$ \\
\hline 15 & B & MORE QUALITY & 43 & B & MORE SOLID \\
\hline
\end{tabular}

\footnotetext{
${ }^{2}$ In common usage in Turkish, it means something like "very good, excellent, wonderful".
} 


\begin{tabular}{|c|c|c|c|c|c|}
\hline 16 & A & - & 44 & B & - \\
\hline 17 & B & NICE TASTE & 45 & B & SWEETER \\
\hline 18 & B & $\begin{array}{l}\text { CHOCOLATE TASTE } \\
\text { MORE INTENSIVE }\end{array}$ & 46 & B & $\begin{array}{l}\text { TASTE MORE } \\
\text { INTENSIVE }\end{array}$ \\
\hline 19 & A & $\begin{array}{l}\text { TASTES BETTER AND } \\
\text { MORE FLUID }\end{array}$ & 47 & B & DELICIOUS \\
\hline 20 & B & MORE DELICIOUS & 48 & B & HIGH QUALITY \\
\hline 21 & B & - & 49 & B & NICE \\
\hline 22 & B & A BEAUTIFUL TASTE & 50 & A & GOOD TASTE \\
\hline 23 & B & $\begin{array}{l}\text { I THINK THIS IS } \\
\text { BEAUTIFUL }\end{array}$ & 51 & B & DESSERT \\
\hline 24 & $\mathrm{C}$ & $\begin{array}{l}\text { I DID NOT SEE THE } \\
\text { DIFFERENCE }\end{array}$ & 52 & B & $\begin{array}{l}\text { HAS A GOOD } \\
\text { TASTE }\end{array}$ \\
\hline 25 & B & A PLEASANT TASTE & 53 & B & - \\
\hline 26 & A & SO DELICIOUS & 54 & B & $\begin{array}{l}\text { TASTE MORE } \\
\text { PLEASANT }\end{array}$ \\
\hline 27 & B & WAS GOOD & 55 & B & GOOD \\
\hline 28 & B & $\begin{array}{c}\text { MORE BEAUTIFUL THAN } \\
\text { OTHERS }\end{array}$ & 56 & $\mathrm{C}$ & BOTH THE SAME \\
\hline
\end{tabular}

When Table 3 was analyzed, all of the subjects gave reasons for the taste of the product as the reason for their liking and did not state anything that they were affected by the price. However, when the answers given by the subjects to the 4 th and 5th questions asked in the experiment are analyzed, it is seen that the subjects are actually affected by the price. Although we think that we act with our mind, in reality we are unaware of many things in daily life.

According to the optimization condition, which is the equilibrium condition of neoclassical economics, the individual behaves in a way that maximizes its benefit. In order to analyze this condition, the subjects were asked, Which would you buy if you were to buy? The question has been asked. Here, the rational economic individual should take an attitude in an effort to maximize the benefit with cost minimization and choose the product with a unit price of 17.25 TL. Because the comparison is in the form of tasting and is made between two products that are the same. However, according to the result, $46 \%$ of the subjects were able to provide the benefit maximization condition with cost minimization, while $54 \%$ did not act to meet this condition. At the same time, this situation does not support the law of demand. 
According to the demand law, the product with a lower price should be preferred at a higher rate. Because the two products tasted should be preferred at the same rate. There is no such product as Low or Giffen. In addition, the high demand for the high-priced product may have brought the Veblen effect to mind. However, under the influence of Veblen, vanity comes to the fore. Individuals increase their demand for goods, whose prices are rising with the effect of showing off. This is not the case here either. Demand theory is a scientific reality. The analysis here is not intended to criticize the demand theory. Although the result is exceptional, it reveals the issues that mainstream economics ignores with the assumption of pure rational individual.

While the subjects were making their evaluations, they asked the subjects to understand the underlying mechanism, Why might people have chosen / liked / preferred the one with the unit price of 17.25 TL or the one with the unit price of $21.5 \mathrm{TL}$ when both had the same product? The answers given by the subjects to the question asked in the form are shown in Table 4.

Table 4: Answers Given by the Subjects to the 4th and 5th Questions

\begin{tabular}{|c|c|c|c|}
\hline Subject & Answer & Subject & Answer \\
\hline 1 & $\begin{array}{c}\text { CHOOSE A; TRICK } \\
\text { CHOSE B; HIGH PRICE }\end{array}$ & 29 & $\begin{array}{c}\text { A; CHEATING } \\
\text { B; PRICE }\end{array}$ \\
\hline 2 & PSYCHOLOGICAL & 30 & $\begin{array}{l}\text { I MARKED C BECAUSE I THINK } \\
\text { THE BOTH WERE THE SAME }\end{array}$ \\
\hline 3 & $\begin{array}{c}\text { CHOOSE A; IDEA OF BEING } \\
\text { TRICKED } \\
\text { CHOSE B; HIGH PRICE }\end{array}$ & 31 & $\begin{array}{c}\text { A; TRAP } \\
\text { B; QUALITY DUE TO THE PRICE }\end{array}$ \\
\hline 4 & $x$ & 32 & $\begin{array}{c}\text { A; THE LOW PRICE IS } \\
\text { ATTRACTIVE } \\
\text { B; HIGHER PRICE IS GOOD }\end{array}$ \\
\hline 5 & $\begin{array}{l}\text { CHOOSE A; CHEATING } \\
\text { CHOSE B; FOR PRICE }\end{array}$ & 33 & 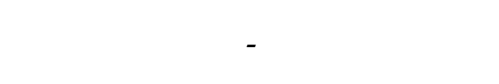 \\
\hline 6 & $\begin{array}{c}\text { POSSIBLE } \\
\text { PSYCHOLOGICAL }\end{array}$ & 34 & $\begin{array}{l}\text { I THOUGH BOTH WAS } \\
\text { DIFFERENT }\end{array}$ \\
\hline 7 & $\begin{array}{l}\text { DUE TO ROOM } \\
\text { TEMPERATURE }\end{array}$ & 35 & ANYTHING CAN HAPPEN \\
\hline 8 & $\begin{array}{c}\text { CHOOSE A; } \\
\text { MANIPULATION } \\
\text { PERCEPTION } \\
\text { CHOSE B;PERCEPTION OF } \\
\text { ALWAYS EXPENSIVE IS } \\
\text { BETTER }\end{array}$ & 36 & $\begin{array}{c}\text { PEOPLE ALWAYS CHOOSE } \\
\text { EXPENSIVE } \\
\text { BECAUSE THE HIGHER PRICE IS } \\
\text { BETTER. } \\
\text { OTHERS MAY THINK THAT IT IS } \\
\text { CHEATING }\end{array}$ \\
\hline
\end{tabular}


CHOOSE A; THRICK

9

CHOSE B; PEOPLE ALWAYS CHOOSE THE HIGHER (EXPENSIVE) PRICE.

CHOOSE A; IT IS THE BEST PRODUCT WHICH IS

$$
\text { EXPENSIVE }
$$

CHOSE B; LOW PRODUCT IS SCAM

CHOOSE A; ON PURPOSE

CHOSE B; HIGHER PRICE IS GOOD

PEOPLE HAVE DIFFERENT THOUGHTS

A; THOUGHT OF MANIPULATION

B; THE THINK OF EXPENSIVE IS QUALITY

THOUGHT MAY BE BECAUSE THE STRUCTURE IS DIFFERENT

CHOOSE A; PEOPLE THINK THERE THERE A CHEAT CHOSE B; EXPENSIVE PRODUCT COMES PSYCHOLOGICALLY MORE DELICIOUS PEOPLE MAY HAVE DIFFERENT TASTE THERE IS A DIFFERENCE IN BOTH BUT THE MATTER IS NOT

CHEAP AND EXPENSIVE, I WOULD PREFER $B$. CHOOSE A; CHEAPEST SELLERS THINK THAT THEY WERE DECEPTION CHOSE B; THINKING EXPENSIVE PRODUCT IS BETTER

I CAN'T MIND SOMETHING FOR PRICE; TRICK CHOSE B; HIGHER IS GOOD CHOOSE A; DUE TO THE PRICE DECEPTION, GOOD QUALITY OF 21.5 TL

FOR PRICE; TRICK CHOSE B; HIGHER IS GOOD

CHOOSE A;BECAUSE 21
I THINK PEOPLE ALWAYS

WANT TO BUY THE CHEAPEST BECAUSE IT IS POOR

\section{CHOOSE A; OBFUSCATION} CHOSE B; HIGH PRICE

I DID NOT KNOW THAT 46

A; TRAP

B; QUALITY DUE TO THE PRICE

\section{A PSYCHOLOGICAL SITUATION}

PEOPLE THINK THAT THE 49 PRODUCT WITH HIGHER PRICE IS BETTER AS THE QUALITY AND THE MATERIAL USED.
PEOPLE FALL IN THE PRICE

TRAP, THEY BECOME EXPENSIVE QUALITY 
CHOSE B; MAY THINK THE

CHEAPER IS CHEATING

$$
\text { ALSO }
$$

17.25, BECAUSE THEY

CONSIDER THAT THEY

22
HAVE BEEN FOOLED

21.5, HIGH PROCE ALWAYS GOOD

TWO TASTED AT THE SAME TIME MAY NOT BE

TASTED FOR FOR PRICE; TRICK CHOSE B; HIGHER IS GOOD THE PRODUCT WHICH IS EXPENSIVE TO PEOPLE ALWAYS COMES BETTER OR SWEET LIKE, THEREFORE THEY MAY HAVE CHOSEN B

FOR PRICE; TRICK CHOSE B; HIGHER IS GOOD

PEOPLE TAKE THE B BECAUSE THE EXPENSIVE PRODUCT IS QUALITY. PRICE IS NOT LOW IN A, IT IS INTENTALLY CHANGED B IS SELECTED BECAUSE THE PRICE IS HIGH
OTHERS MAY THINK THAT IT IS CHEATING

I CHOOSE A, BECAUSE I CHEAP, I DON'T KNOW THE OTHER

LIKE REVERSE PSYCHOLOGY

51

THINKING THAT A WAS GOOD, SO I WAS DOING IT.

"B" SURPRISED ME DUE TO THE PRICE

"A" CHEAT

"B" PRICE IS HIGH QUALITY

PEOPLE CAN BE ABLE TO

54

CHANGE THEIR DECISION ON TASTE

CHOOSE A; TRICK CHOSE B; HIGH PRICE

PRICE AND CHEAT THOUGHT

When the answers given by the subjects were analyzed, $60.7 \%$ of them evaluated that they might have been caught in the perception of price and confusion. While those who are caught in the perception of confusion have the idea that the price is deliberately written low and in reality the lower price is better, those who choose the product with a higher price have the perception that the higher priced one will be of higher quality. While $32.2 \%$ of the subjects stated other reasons, $7.1 \%$ left it blank. 


\section{Conclusion}

The utility phenomenon should be subjected to a multi-functional analysis rather than a one-sided evaluation. It is now shallow to define utility maximization as an increase in pleasure on the individual as a result of an increase in the amount of goods consumed. Although this definition is real, the effect of perceptions is too great to ignore. In many parts of their daily lives, people make decisions based on their perceptions. Our perceptions are not always rational. As seen in this experiment, although the same product is tasted and the sense of taste is a neurophysiological process (that is, it starts from the tongue and goes directly to the brain), the perceptions that occur do not develop in this way. Nowadays, when our perceptions have come to the fore, the need to consider the concept of utility from this perspective arises. As a matter of fact, although we are creatures that pursue utility maximization, considering the benefit only depending on the amount of goods people consume makes it difficult to understand the concept of real benefit.

The acceptance of the rational individual ideal typing as an entity pursuing utility maximization actually makes it difficult to analyze the utility phenomenon. Likewise, the utility phenomena of individuals who act with their perceptions in many parts of their daily life are also shaped on this axis. Perceptions can change by being affected by things we are not aware of, even in a neurophysiological process that starts from the language, such as the sense of taste, and goes directly to the brain. This situation reveals that people are always pure rational and cannot act with their mind.

The suggestion to be excluded from this study is that when people cannot make the decisions that may be in their favor due to their cognitive constraints, policies in the form of impulse practice should be developed, as Richard Thaler has shown in his studies, that will tolerate their prejudices and enable them to make rational decisions, but will not interfere with personal choice rights while doing so. For example, the design of promotions and presentations that concern the future of individuals, such as a savings decision, but when they are not rational due to different perception mistakes when evaluating from 
today, taking this issue into account will enable them to reach a wider customer base for private companies in the private pension sector that are intermediaries for insurance. In this way, it will be possible to make more rational decisions for the long term as a result of the awareness of the possible risks that people may face in their future, and at the same time, the country's savings rates will increase.

This research shows that people can develop different perceptions even in the same situation and thus deviate from the assumption of rationality, and the concept of perceived utility by drawing attention to other issues that are neglected by mainstream economics towards the rational individual assumption, which is the first criticism of behavioral economics and which are effective in our many decision moments, including our economic decisions. It contributes to the literature as a continuation of existing studies. Although behavioral economists have been carrying out studies that show that real people are not selfish by acting only with their mind, citing cognitive constraints as justification, there is a need for deeper analysis to complete the missing aspects of the real person. As a matter of fact, the stronger the understanding of human, which is the main purpose of social sciences, the more validity of the theory and policies to be formed will increase. 
Ethics Statement: The authors declare that ethical rules are followed in all preparation processes of this study. In case of detection of a contrary situation, BIIBBFAD Journal does not have any responsibility and all responsibility belongs to the authors of the study. The Ethics Committee Approval of this study was obtained by the Sakarya University Rectorate Ethics Committee on 01.12.2021, with the decision numbered 40/02.

Author Contributions: İbrahim CEVIZLİ contributed to the determination of the subject, the review of the literature, the creation of the data set, the analysis of the data, the reporting of the data and the conclusion sections. Mahmut BİLEN contributed to the literature and the conclusion. 1st author's contribution rate is approximately $70 \%$, 2nd author's contribution rate is $30 \%$.

Conflict of Interest: There is no conflict of interest between the author.

Acknowledgement: We would like to thank the Editorial Board of BIIBBFAD Journal for their intense interest and efforts and the referees for their contribution.

\section{References}

Bentham, J. (1996). The Collected Works Of Jeremy Bentham: An Introduction To The Principles of Morals And Legislation. Clarendon Press.

Bulmuş, İ. (2008). Mikroiktisat. Ankara: Oktman Yayınc1lık.

Cevizli, İ. \& Bilen M. (2021). Duyguların rasyonel iktisadi kararlarımız üzerindeki etkisi. Insan ve Toplum Dergisi, 11(2), 19-46.

Dinler, Z. (2015). Mikro Ekonomi. 26. Baskı. Bursa: Ekin Yayın Dağıtım.

Dumludağ, D., Gökdemir, G., Neyse, L. ve Ruben, E. (2018). İktisatta Davranışsal Yaklaşımlar. 2. Baskı. Ankara: İmge Kitabevi.

Eren, E. (2011). Yeni İktisatta Ortak Noktalar. Ercan Eren ve Metin Sarfati (Ed.), İktisatta Yeni Yaklaşımlar, 1. Baskı İçinde, Sayfa: 1345, İstanbul: İletişim Yayınları

Frey, B.S., \& Stutzer A. (2002). What can economist learn from happiness research?. Fournal Of Economic Literatüre, 40(2), 402435. 
Gökdemir, Ö. \& Öztürk, M. (2018). Fayda, Sosyal Seçim ve Mutluluk. İktisatta Davranışsal Yaklaşımlar, 2. Baskı İçinde, Sayfa: 199-220). Ankara: İmge Kitabevi.

Hicks, J. R. \& Allen, R. G. (1934). A Reconsideration Of The Theory Of Value. Part I. Economica, 1(1), 52-76.

Kırpınar, İ. (2019). Bilişsel Psikoloji. İstanbul: Psikonet Yayınları.

Küçükkalay, A.M. (2008). İktisadi Düşünce Tarihi. İstanbul: Beta Yayınları.

Laird, D.A. (1932). How The Consumer Estimates Quality By Subconscious Sensory Impressions. Journal Of Applied Psychology, 16(3), 241-246.

Mendelson, M. (2002). Many Sides: A Protagorean approach to the Theory. Practice And Pedagogy Of Argument, (Vol. 5). Springer Science \& Business Media.

Mlodinow, L. (2013). Subliminal: Bilinçdışımız Davranışlarımızı Nasıl Yönetir?. İstanbul: Okuyan Us.

Mullainathan, S. \& Thaler, R. (2000). Behavioral Economics. International Encylopedia Of Social And Behavioral Sciences, p. 1094.

North, A. C., Hargreaves, D. J., \& McKendrick, J. (1997). In-Store Music Affects Product Choice, Nature, 390(6656), 132-132.

Packard, V. (1957). The Hidden Persuaders. New York: David McKay, 16.

Paulus, M.P. \& Frank, L.R. (2003). Ventromedial prefrontal cortex activation is critical for preference judgments. Neuroreport, 14(10), 1311-1315.

Yayar, R. \& Karaca, Ö.E. (2019). Davranışsal iktisat bağlamında kamu çalışanlarının tüketim davranış eğilimleri. Akdeniz İ̈BF Dergisi, 19(1), 1-29.

Yayar, R. \& Oruç, S. (2020). Tokat ili kentsel alanda tüketicilerin gösterişçi tüketime yönelik eğilimleri. Çukurova Üniversitesi İIBF Dergisi, 24(1), 35-55. 
Bingöl Üniversitesi İktisadi ve İdari Bilimler Fakültesi Dergisi

Yıl/Year: 2021 Cilt/Volume: 5 Say1/Issue: 2

Yılmaz, F. (2009). Rayonalite İktisat Özelinde Bir Tartışma. İstanbul:

Paradigma Yayıncilik. 